\title{
Monitoring of Fruit and Vegetable Waste Composting Process: Relationship between Microorganisms and Physico-Chemical Parameters
}

\author{
Cristina Ghinea *(D) and Ana Leahu \\ Stefan cel Mare University of Suceava, Faculty of Food Engineering, 13 Universitatii Street, \\ 720229 Suceava, Romania; analeahu@fia.usv.ro \\ * Correspondence: cristina.ghinea@fia.usv.ro
}

Received: 21 January 2020; Accepted: 2 March 2020; Published: 5 March 2020

\begin{abstract}
The aim of this study was to investigate and evaluate the composting potential of fruit and vegetable waste with sawdust in different combinations and to establish the relationship between microorganisms and physico-chemical parameters. Three samples were made with the $\mathrm{C} / \mathrm{N}$ ratios of 50 (sample 1), 45 (sample 2), and 30 (sample 3) by adding fruit waste (apple, banana, orange, and kiwi peels) and vegetable waste (cabbage leaves, potato and carrot peels). The total amount of fruit and vegetable waste was approximately $2 \mathrm{~kg}$ in each sample to which different quantities of sawdust were added $(1.23,0.14$, and $0.203 \mathrm{~kg})$ in order to obtain the $\mathrm{C} / \mathrm{N}$ ratios proposed and to limit the odor. Composting process was monitored over 70 days, while physico-chemical and microbiological analyses were performed. Results showed that in the first week $\mathrm{pH}$ is acidic and electrical conductivity values are high for all three samples, and then the $\mathrm{pH}$ values increase during the composting process, while electrical conductivity values decrease. The nitrogen content is low in all samples and will decrease during the first five weeks of the composting process, then begin to increase slightly. $\mathrm{Cr}, \mathrm{Cu}$, $\mathrm{Ni}$, and $\mathrm{Zn}$ values in the all three compost samples are below threshold values. During the composing process the microbial communities are constantly changing. The compost was successfully obtained and meets the requirement standards for agricultural use. It can be concluded that there is statistically significant association between the microorganisms and physico-chemical indicators.
\end{abstract}

Keywords: aerobic process; food waste; heavy metals; microorganisms; nitrogen content

\section{Introduction}

Every year, municipal solid wastes (MSW) are generated in large amounts. Only in the EU, in 2018, over 250,000 thousand tons of waste were generated, while in Romania in the same year, 5296 thousand tones were generated [1]. The amount of waste generated in Romania decreased from $313 \mathrm{~kg}$ per capita in 2010 to $272 \mathrm{~kg}$ per capita in 2017 following the same decreasing tendency observed also at the European Union level (from $503 \mathrm{~kg}$ per capita in 2010 to $487 \mathrm{~kg}$ per capita in 2017) [1,2]. In 2018, according to [1] $272 \mathrm{~kg}$ solid waste per capita was generated in Romania and it is assumed that on average Europeans generate $488 \mathrm{~kg}$ per capita [1]. It can be observed that waste generation indicators in Romania are just over half of the European average and possible explanations would be low consumption of products, underestimation of waste amounts by the sanitation operators, a large part of the landfills are nonconforming, many of them without weighing [2]. Over time it was determined that the organic fraction has the highest percentage from the EU MSW composition and according to [3] in Europe, the main fraction of municipal solid waste is food waste (45\%). In Romania, the authors of [4] conducted a study for determination of MSW composition in the North -East region (which includes six counties) of the country and established that organic waste represents the fraction 
with the highest percentage (59.2\%-64.4\% for 2009-2010). Bio-waste represents the largest fraction from the composition of household and similar waste (57.9\% as average) [2,5]. Although the amount of municipal waste is continuously decreasing, biodegradable waste does not follow the same trend.

At the European level, composting and anaerobic digestion of bio-waste, which includes food waste among the other biodegradable waste, are encouraged [6]. Food wastes are biodegraded by microorganisms under aerobic conditions during the composting process and a humus material, that can be used for soil improvement, is obtained [7]. The composting process can take place under natural or controlled conditions and is influenced by various physico-chemical parameters like $\mathrm{pH}$, electrical conductivity, moisture, $\mathrm{C} / \mathrm{N}$ ratio, temperature, aeration and particle size [8]. Besides compost, through the bio-waste anaerobic digestion, biogas is also obtained. Both processes are considered environmentally friendly and used extensively in order to divert organic materials from landfills $[3,9,10]$. Regarding the treatment of municipal biodegradable waste in Romania, the main method used is composting. At present, in Romania, there is no anaerobic digestion plant for municipal waste in operation. In 2016, 22 composting plants with a total capacity of approx. 180,000 tons/year existed. At a national level, there are 45 composting plants that are under construction or are under implementation, out of which 22 are in operation, 18 are or are being implemented by projects, not yet in operation and five are authorized composting plants, which are not currently working. According to [2] in 2014, the material recycling rate was about $5 \%$ and the composting rate was $8 \%$. Currently, the amount of biodegradable municipal waste composted is very low. In municipal waste composting facilities, only green waste from parks and gardens is currently being used. Thus, it can be appreciated that the utilization of food waste through composting is insignificant [2].

In this context, it is important to study the composting process of food waste, in particular fruits and vegetable waste, which, according to [11], contributes to almost half of the total food waste generated by households. In 2010, the amount of fruit and vegetables purchased in the EU were 52 and $71 \mathrm{~kg}$ per person and year, respectively, from which $14 \mathrm{~kg}$ of fruit were wasted (9 $\mathrm{kg}$ unavoidable waste or inedible fractions and $5 \mathrm{~kg}$ avoidable waste), while $21 \mathrm{~kg}$ of vegetables were wasted (12 kg unavoidable and $9 \mathrm{~kg}$ avoidable waste). The fruit and vegetable waste is highly perishable products, relatively cheap commodities, and have inedible components. For example, the inedible fractions (in $\%$ of fresh fruits/vegetables) are apples $12 \%$, bananas $35 \%$, kiwis $18 \%$, oranges $24 \%$, cabbages $20 \%$, carrots $19 \%$, and potatoes $16 \%$. Average EU consumption of fresh fruits is apples $47.70 \mathrm{~g} /$ person/day, bananas $18.70 \mathrm{~g} /$ person/day, kiwi $4.24 \mathrm{~g} /$ person/day, and oranges $13.42 \mathrm{~g} /$ person/day, while the average EU consumption of fresh vegetables is cabbages $5.90 \mathrm{~g} /$ person/day, carrots $13.86 \mathrm{~g} / \mathrm{person} / \mathrm{day}$, and potatoes $78.27 \mathrm{~g} /$ person/day [11]. If, for unavoidable food waste, treatment processes based on organic biodegradation should be applied, for generation of avoidable waste, waste preventive measures should be taken starting from people education in order to change their behavior, habits, and attitudes [10,12].

In the literature, there are different types of reactors used for solid waste composting and various experimental designs. For example, in [13] composting of four different samples containing vegetable wastes in various proportions was performed in PET containers. They performed manual aeration once per day over 35 days. Five different mixture of waste samples were composted in plastic reactors by [14]. The experiments were conducted for 21 days. A reactor from polyvinyl chloride was used by [15] for food waste composting. Approximately $3 \mathrm{~kg}$ of raw materials was put inside the reactor at the beginning of composting and two different runs, A and B, were performed. The authors of [16] used three plastic drums (125 L capacity) with different configurations for food composting. In order to facilitate the natural aeration, they provided holes for two drums and studied the composting process for 60 days. The turning of waste sample was performed only in one drum and a higher degradation rate for this one was observed. In another study, the authors of [17] investigated the food waste composting over 60 days in different drums with $140 \mathrm{~L}$ capacity (two drums with holes, perforated PVC pipe, and turning and only one drum with inoculum addition). The waste was turned once in 
six days. For this study plastic containers were chosen, which were modified in order to perform natural aeration.

According to [3], food waste composting depends on source of waste, composition, high moisture content $(74 \%-90 \%)$, volatile solids to total solids ratio $(80 \%-97 \%)$ and $\mathrm{C} / \mathrm{N}$ ratio (14.7-36.4). Therefore, it is important before the beginning of the composting process, to determine the food waste composition (especially the nitrogen and carbon contents, moisture, but also other parameters such as $\mathrm{pH}$ and electrical conductivity) and to establish the proportion of different food waste types for obtaining the desired $\mathrm{C} / \mathrm{N}$ ratios. After physico-chemical parameter determination, the regression analysis can be successfully used to establish the quantities of each type of waste in order to obtain the desired $\mathrm{C} / \mathrm{N}$ ratios [18]. The development of microorganisms during the composting process is particularly influenced by the $\mathrm{C} / \mathrm{N}$ ratio which plays a crucial role because it represents the carbon and nitrogen sources necessary for their growth. At the beginning of the composting process the $\mathrm{C} / \mathrm{N}$ ratio should be around 25-30, but many authors have used different $\mathrm{C} / \mathrm{N}$ ratios with values between 20 and 50 [3]. Determination of relation between microorganisms and physico-chemical indicators helps for a better understanding of the composting process, its improvement, and the proper selection of the types of waste subject to composting.

In this context, the aim of this paper was to obtain compost at laboratory level from fruit (apples, bananas, kiwis, and oranges) and vegetable (cabbages, carrots, and potatoes) waste collected from different Romanian households and one canteen. The composting process was monitored over 10 weeks, while physico-chemical and microbiological analyses were performed and the relation between microorganisms and physico-chemical indicators was determined.

\section{Materials and Methods}

The composting process was carried out at laboratory level within the Faculty of Food Engineering, Stefan cel Mare University of Suceava, Romania during the period March-June 2018.

Food wastes were collected from the canteen of Stefan cel Mare University of Suceava and from different households. The wastes were selectively collected, prepared (shredded, weighed) in the laboratory, and placed in plastic containers (Figure 1a). The plastic containers were modified by providing two layers of holes in order to facilitate the natural air circulation. The composting process was monitored over 10 weeks. During the composting, the return and mixing of samples once at six days was carried out. After this period compost was obtained (Figure 1b) which can be used as fertilizer for soil. Figure 1c illustrates plant growth on our compost.

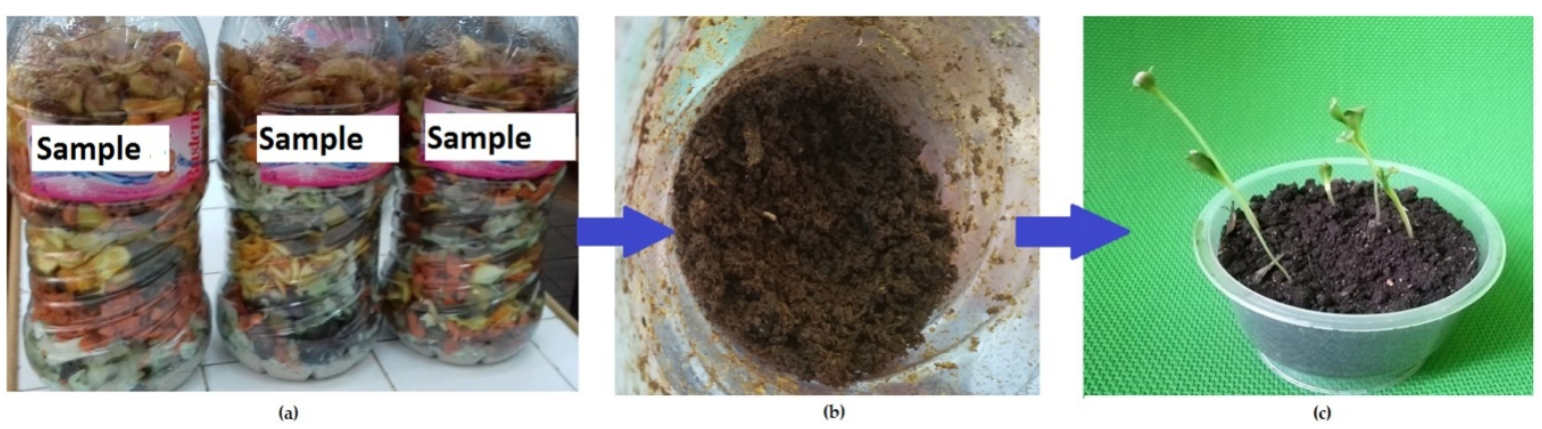

Figure 1. (a) Food waste samples prepared for composting; (b) the obtained compost; (c) plants grown in the obtained compost.

The composition of the three samples analyzed in this study is presented in Figure 2. The amounts of sawdust were calculated based on the equation proposed by [18]. 

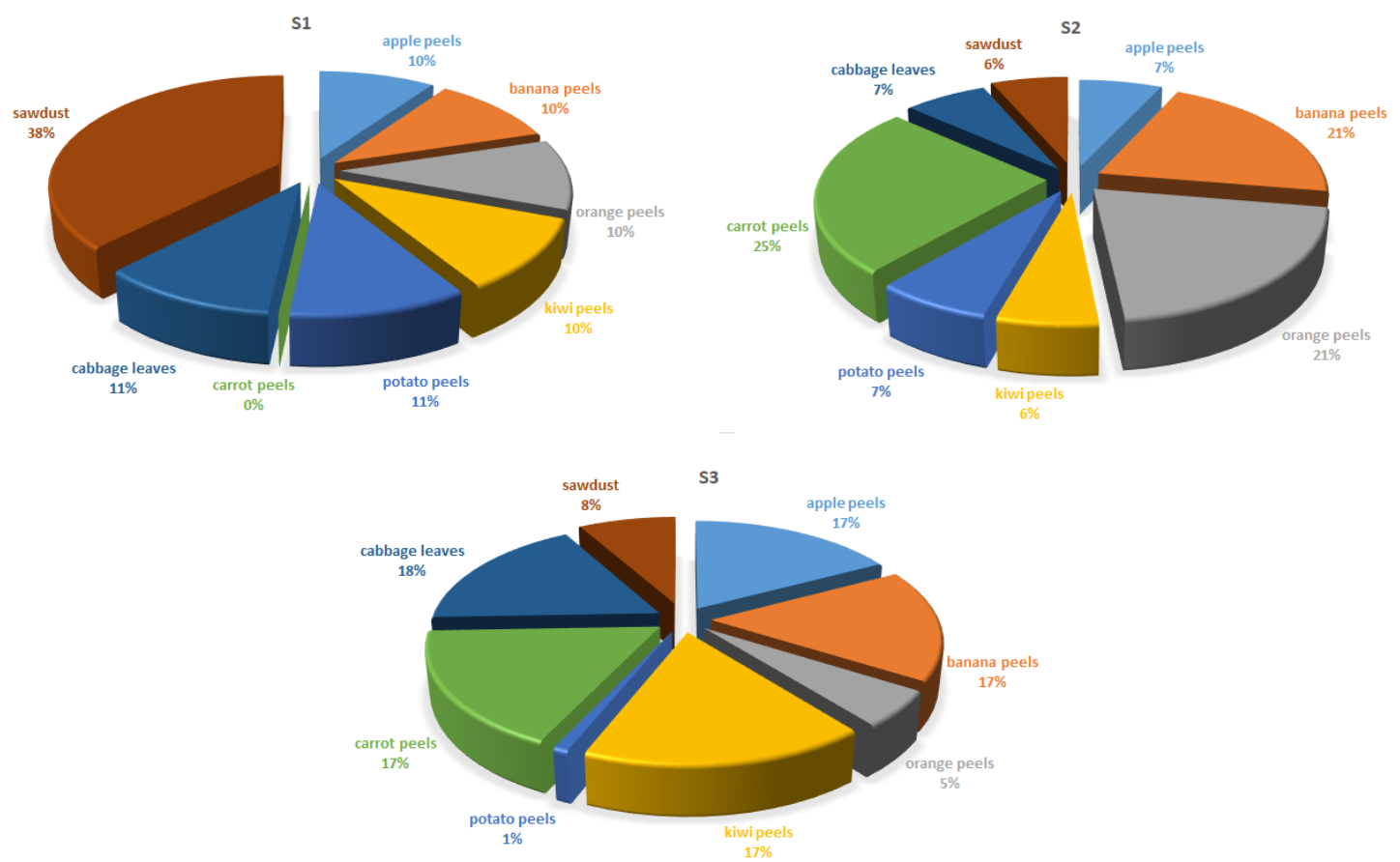

Figure 2. Composition of the analyzed samples.

$\mathrm{pH}$ and electrical conductivity (EC) were measured with a pH meter IQ240 and CyberScan CON 510 Conductivity Meter (Eutech Instruments, Vernon Hills, Illinois, USA). Moisture (M) was determined by oven drying $\left(105^{\circ} \mathrm{C}\right.$ for $24 \mathrm{~h}$ up to constant weight), while ash content was obtained by burning food waste samples at $550{ }^{\circ} \mathrm{C}$ for $4 \mathrm{~h}$. An oven manufactured by Nabertherm (Nabertherm, Lilienthal, Germany) was used. The nitrogen content was determined by applying the Kjeldahl method and using DK Series Kjeldahl Digestion Units_VELP Scientifica (VELP ScientificaSrl, Usmate, Italy). The carbon content was determined by ignition at $550{ }^{\circ} \mathrm{C}$ and calculated according to [18]. For determination of heavy metals content from obtained compost, a mass spectrometer with inductively coupled plasma mass spectrometry (ICP-MS) Agilent Technologies 7500 Series (Agilent, Santa Clara, CA, USA) was used.

For microbiological assessments, spread plate techniques were used. Samples were collected from several places of the compost material and thoroughly mixed to achieve a mean sample, and then $5 \mathrm{~g}$ were placed in a bag with $45 \mathrm{~mL}$ of sterile distilled water and homogenized using a BagMixer (InterScience, Saint-Nom-la-Bretèche, France). Dilutions were made in sterile saline solution $(0.9 \% w / v$ $\mathrm{NaCl}$ ) based on the method described by $[19,20]$. Under sterile conditions, $1 \mathrm{~mL}$ of filtered and serially diluted (1/1000) homogenate was spread onto medium plates. Mediums used for cultivation were Potato Dextrose Agar (PDA) for yeast and mold counting, Plate Count Agar (PCA) for total aerobic counts, deMan, Rogosa, Sharpe (MRS) Agar for lactic bacteria counts, Coliform Agar for coliform counts. All mediums were purchased from Sigma Aldrich (Taufkirchen, Germany) as ready-made plates and incubated under producer specifications, using AnaeroCult system (Sigma Aldrich, Germany) for lactic acid bacteria cultivation. The PDA plates were incubated for 4 days at $25^{\circ} \mathrm{C}$, while PCA plates at $37^{\circ} \mathrm{C}$ for $24 \mathrm{~h}$. Over 3 days MRS plates were incubated at $35^{\circ} \mathrm{C}$, under anaerobic conditions, while Coliform Agar plates were incubated for $48 \mathrm{~h}$ at $37^{\circ} \mathrm{C}$. The authors of [21] incubated the Petri plates at $37^{\circ} \mathrm{C}$ (24 h) for counting of Escherichia Coli, Cellulolytic, Amylolytic, and Nitrogen fixing bacteria. In [22] the authors incubated the plates at 30 and $55^{\circ} \mathrm{C}$, respectively. In [23] the authors determined the total counts of mesophilic bacteria and fungi after incubation at $28{ }^{\circ} \mathrm{C}$, and after incubation at $50{ }^{\circ} \mathrm{C}$ for thermophilic bacteria. The authors of [24] performed incubation at $25^{\circ} \mathrm{C}$ for mesophilic bacteria and at $55^{\circ} \mathrm{C}$ for thermophilic bacteria. 
After incubation, colonies were counted, and results were calculated taking into account the dilution factor and the weight of the sample used and expressed as colony forming units (CFU)/gram of compost. For each compost variant, three plates from each type of medium were used and results expressed as means $+/-$ standard deviations.

The obtained data were analyzed with Minitab 17 statistical software. Pearson's correlation matrix of heavy metals concentrations in the compost samples was determined. In order to observe if there is any correlation between physico-chemical and microbiological parameters Pearson correlation was used. Principal component analysis was also performed. Poisson Regression Analysis was applied to find a mathematical relation between microorganisms and physico-chemical parameters.

\section{Results}

$\mathrm{pH}$, electrical conductivity, moisture, and ash content were measured every week, while nitrogen and carbon contents were determined at the beginning, in the middle, and the end of the composting period. Experiments were performed in triplicate.

The $\mathrm{pH}$ will always decrease at the start of the aerobic degradation process due to the production of fatty acids, $\mathrm{CO}_{2}$, and nitrification, but will increase again with the decomposition of organic matter by microorganisms [25]. Changes in $\mathrm{pH}$ values may be an important indicator of microbiological activity. The authors of [25] stated that there exists a correlation between lactic acid bacteria high concentration and low $\mathrm{pH}$ in the first phases of composting.

It is considered that during the composting process a $\mathrm{pH}$ between 7.5 and 8.5 supports microbial decomposition of organic matter. In the first week of our study the $\mathrm{pH}$ was acidic for all three samples (Figure 3a). However, a low $\mathrm{pH}$ and the appearance of unwanted odors due to the generation of fermentation products indicate the need for oxygen, so to raise $\mathrm{pH}$ values and to prevent the development of anaerobic conditions, a more efficient aeration was achieved, and a certain amount of sawdust was added. It can be seen that $\mathrm{pH}$ values increased starting with the second week for all three samples (Figure 3a). Anaerobic conditions may occur at any stage of composting if the aeration is insufficient to negatively influence the composting process, therefore continuous aeration is required to avoid the occurrence of anaerobic microorganisms. In general, the $\mathrm{pH}$ value should be between 7 and 8 [26,27], and from Figure $3 \mathrm{c}$ it can be seen that the values are within this $\mathrm{pH}$ range. For sample $\mathrm{S} 1$ the mean value of $\mathrm{pH}$ is 7.9 , while for $\mathrm{S} 2$ and $\mathrm{S} 3$ the $\mathrm{pH}$ mean values are around 8.2 (Figure 3c). $p$-values for samples 2 and 3 are lower than the significance level of 0.05 which means that the data do not follow the distribution.

$\mathrm{pH}$ and electrical conductivity are parameters that influence the growth of bacteria and fungi. The variations of electrical conductivity depend on the amount of mineral salts dissolved in suspension, over time, for the three samples. In the first week the electrical conductivity was between 830 and $859 \mu \mathrm{S} / \mathrm{cm}$ (Figure 3b). There was a decrease of electrical conductivity values until the end of the experiment to the following values: $368 \mu \mathrm{S} / \mathrm{cm}$ for S1, $299 \mu \mathrm{S} / \mathrm{cm}$ for S2, and $362 \mu \mathrm{S} / \mathrm{cm}$ for S3 (Figure 3b). All samples had anEC under $1000 \mu \mathrm{S} / \mathrm{cm}$ due to the fruit and vegetable waste according to [28]. Figure 3d illustrates the probability plot for EC of the three samples (the EC mean values were 617.4 $\mu \mathrm{S} / \mathrm{cm}$ for S1, $654.3 \mu \mathrm{S} / \mathrm{cm}$ for S2, and $612.9 \mu \mathrm{S} / \mathrm{cm}$ for S3). The $p$-values of EC for all samples are larger than the significance level, but we cannot conclude that the data follow the distribution.

According to [29] the compost must meet some minimum quality criteria such as $\mathrm{pH} \geq 4$ and $\leq 9$ and $\mathrm{EC} \leq 190 \mathrm{mS} / \mathrm{m}$. The target values for $\mathrm{pH}$ proposed by [30] may vary between 6 and 8 , with an upper limit of 9 . The $\mathrm{pH}$ values obtained for our compost samples are between these values $(7.20$ for compost obtained from S1, 8.85 (S2) and 7.99 (S3)). pH values of 7.7 for home compost and 7.9 for industrial compost were determined by [31]. Regarding the EC values for our compost samples it can be observed that they are lower than the value proposed by $[29,30]$ (target value $<600 \mu \mathrm{S} / \mathrm{cm}$ and an upper limit of $1500 \mu \mathrm{S} / \mathrm{cm}$ ). 


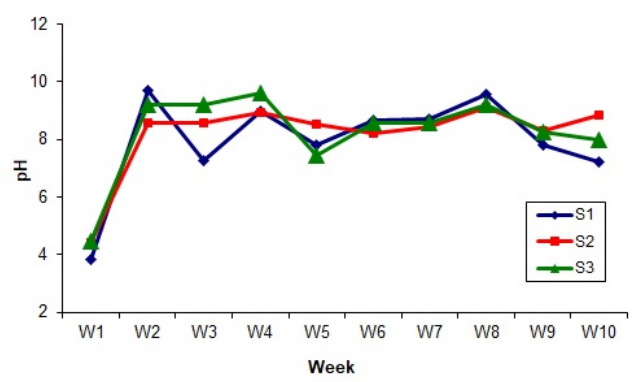

(a)

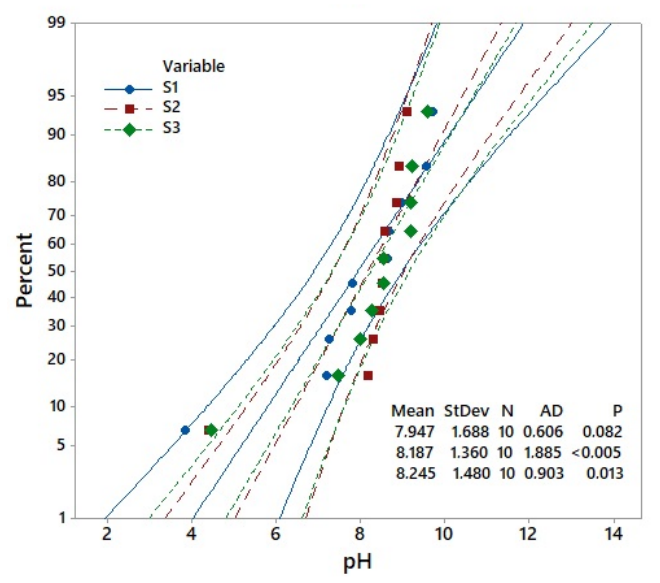

(c)

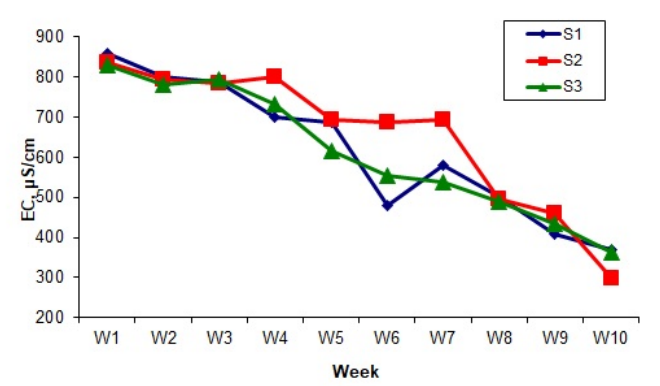

(b)

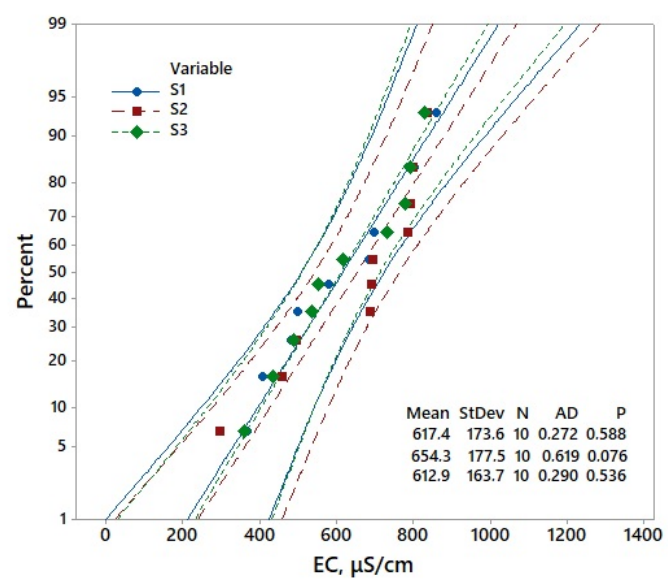

(d)

Figure 3. (a) $\mathrm{pH}$ and (b) electrical conductivity (EC) variations of the samples during composting and probability plot for the three samples analyzed, for (c) $\mathrm{pH}$ and (d) EC.

In the first week of food waste composting, samples S1 and S2 had a moisture content of approximately $83 \%$, while for the other sample a $72.4 \%$ moisture content was determined (Figure $4 \mathrm{a}$ ). It was observed that the moisture content for S1 decreased until the fifth week, then remained constant until the seventh week, and by the tenth week decreased again until $40.9 \%$. During the second week of composting S3 had a moisture content of about $74 \%$, and then increased to approximately $81 \%$ in the third week, followed then by a few fluctuations, and eventually decreased to $41 \%$ in the last week. Additionally, for the second sample, a decrease in the moisture content was registered, some fluctuations being recorded during the composting process. In the tenth week the value of moisture for S2 was around 42\%. The mean values of moisture for S1 and S2 were around 70\% according to Figure 4a ( $p$-value $<0.05)$, while for S3 the mean value was $68.97 \%$ ( $p$-value $<0.05)$ (Figure 4c). Moisture content of compost must be, according to [30], between $35 \%$ and $40 \%$ with an upper limit of $50 \%$. The authors of [31] obtained a value of $44 \%$ of moisture for home composts and $31 \%$ for industrial composts, while the composts obtained by us had a moisture content between $40 \%$ and $42 \%$. During the composting, a higher amount of ash may be noted for S2 followed by S1 and S3 (Figure $4 \mathrm{~b}$ ). In Figure $4 \mathrm{~d}$ the ash content is illustrated, the mean values are around $7.5 \%$ for $\mathrm{S} 1$ and S2 ( $p$-value $>0.05)$ and $6.9 \%$ for S3 ( $p$-value $<0.05)$. 


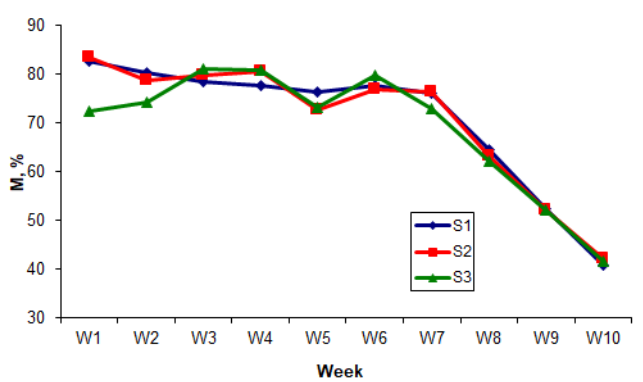

(a)

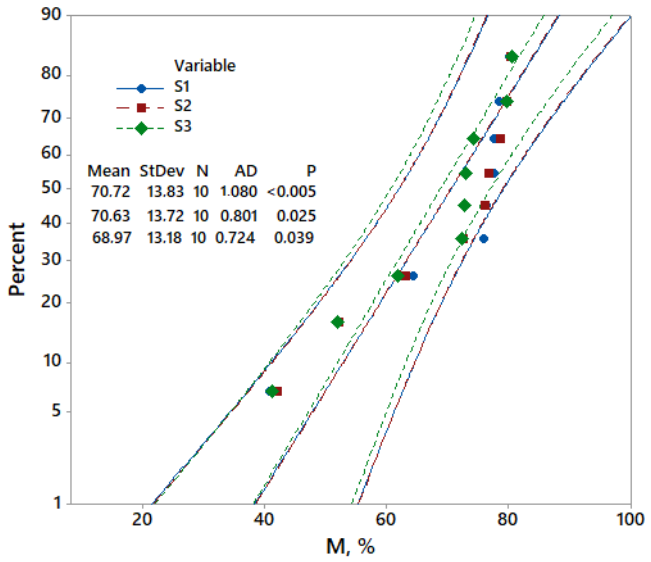

(c)

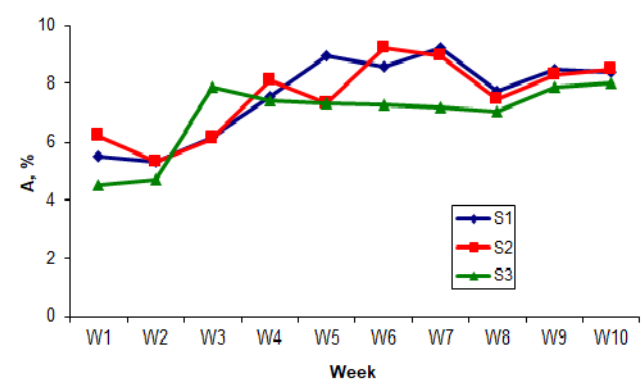

(b)

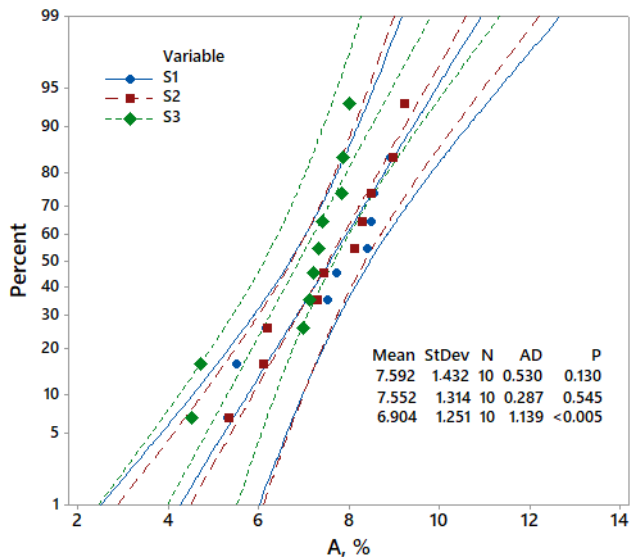

(d)

Figure 4. (a) Moisture and (b) ash content variations of the samples during composting and probability plot for the analyzed samples, for (c) moisture (M) and (d) ash contents.

Apple and banana peel composition and amount influences the $\mathrm{C}$ and $\mathrm{N}$ contents from S1, while cabbage and potatoes peels are the main contributors to the $\mathrm{C}$ and $\mathrm{N}$ percentages determined in sample 3. In S2, the higher $C$ percentage is due to orange and banana peel quantities, while the amounts of orange and carrot peels mainly contributes to N percentage. From Figure $5 \mathrm{a}$ it can be observed that the carbon content decreases during the composting process of the three samples. The highest decrease in carbon content is recorded for $\mathrm{S} 1$ from $55.25 \%$ at the beginning of the composting process to $39.23 \%$ at the end of the process. Carbon contents decreased continuously, since organic materials were decomposed, until a stable value [32]. The nitrogen contents of all samples decreased during the first five weeks of the composting process, then began to increase slightly (Figure 5b). This was also observed by [32] who considered that nitrogen is lost in the early stage through volatilization. In our study at the beginning of composting the $\mathrm{C} / \mathrm{N}$ ratios determined were 50.22 for $\mathrm{S} 1,45.20$ for $\mathrm{S} 2$, and 30.62 for S3, which are very close to those obtained through our calculation of 49.61 (S1), 44.9 (S2), and 31.42 (S3). These $\mathrm{C} / \mathrm{N}$ ratios were used before also by other authors: 30.58 by [33], 49-53 by [34], $\approx 50$ by [35]. The authors of [36] recommended adoption of initial $\mathrm{C} / \mathrm{N}$ values between 25 and 40 or even 50 for composting. During the composting process, the $\mathrm{C} / \mathrm{N}$ values are decreasing [37]. In our study the $\mathrm{C} / \mathrm{N}$ ratios remained roughly constant over the first five weeks for all samples and decreased until the last week as follows: 28.02 for S1, 20.05 for S2, and 18.25 for S3 (Figure 5c). The target value for compost $\mathrm{C} / \mathrm{N}$ ratio is $<20$ according to [31]. It can be observed in our case that only the compost obtained from $\mathrm{S} 3$ has the $\mathrm{C} / \mathrm{N}$ ratio value lower (18) than the target value, while the values of $\mathrm{C} / \mathrm{N}$ ratio for compost obtained from S2 and S1 are around 20 and 28, respectively. In [38,39], values of 18 and 20 for $\mathrm{C} / \mathrm{N}$ ratios in final compost were obtained, respectively. 


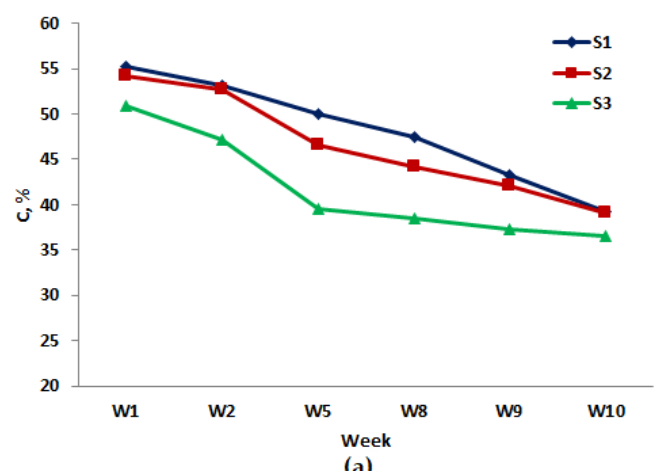

(a)

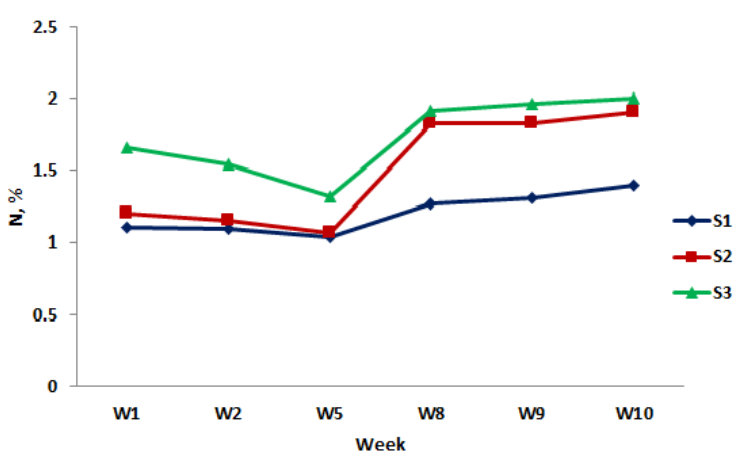

(b)

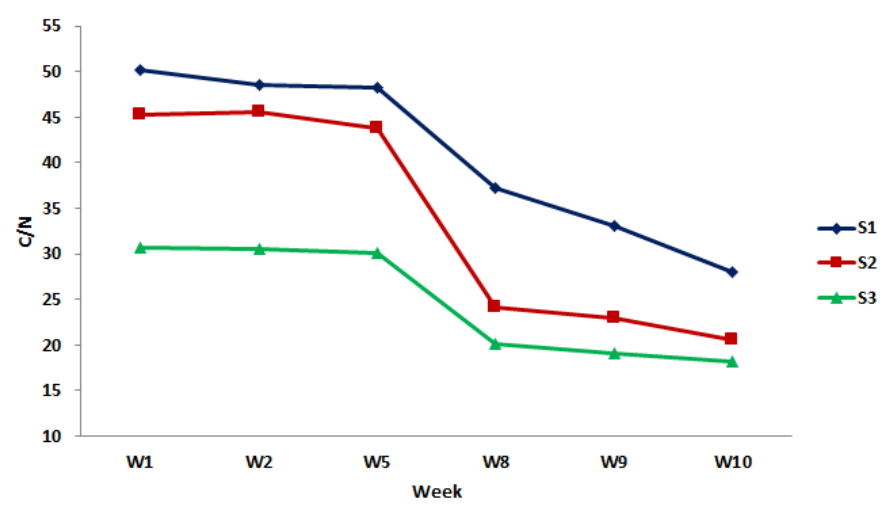

(c)

Figure 5. (a) $\mathrm{C}$ and (b) $\mathrm{N}$ contents, and (c) $\mathrm{C} / \mathrm{N}$ ratio during fruit and vegetable waste composting.

The highest concentration of $\mathrm{Cr}$ is in sample $3(19.42 \pm 0.29 \mathrm{mg} / \mathrm{kg}$ dry weight (DW)), while in samples 2 and $1 \mathrm{Cr}$ concentrations are $11.63 \pm 0.05 \mathrm{mg} / \mathrm{kg}$ DW and $11.34 \pm 0.08 \mathrm{mg} / \mathrm{kg}$ DW, respectively. From Table 1, it can be observed that the $\mathrm{Cr}$ concentrations in all samples do not exceed the limit values. Cobalt concentrations range between 0.45 and $2.18 \mathrm{mg} / \mathrm{kg}$ (mean values), with the highest concentration detected in sample $3(2.18 \mathrm{mg} / \mathrm{kg} \mathrm{DW})$ and lowest concentration registered in sample 2 $(0.45 \mathrm{mg} / \mathrm{kg} \mathrm{DW})$. All three samples exceed, in this case, the limit values since in accordance with EU regulation in the compost composition, cobalt should not be found at all. In this study, the amount of $\mathrm{Cu}$ varied from 3.49 to $5.9 \mathrm{mg} / \mathrm{kg}$ DW. The maximum accumulation of cooper was found in sample 3 , followed by samples 2 and 1 . The $\mathrm{Cu}$ concentrations do not exceed the limit values and it was observed that very low values were recorded compared to the admissible limit values. The highest concentration of Ni was obtained for sample $3(2.78 \pm 0.05 \mathrm{mg} / \mathrm{kg} \mathrm{DW})$, while the lowest concentration was detected in sample $1(1.05 \pm 0.01 \mathrm{mg} / \mathrm{kg} \mathrm{DW})$. The $\mathrm{Zn}$ concentration decreases in the following order: S3 > S2 > $\mathrm{S} 1$. Both the Ni and Zn concentrations determined in this study do not exceed the limits allowed by the legislation (Table 1). From Table 2, it can be observed that there is a strong positive correlation between all the heavy metals ( $r>0.5$ ), which may suggest according to [40] that they have the same origin.

Table 1. Heavy metal values determined for all three samples and the limit values.

\begin{tabular}{cccccccc}
\hline \multirow{2}{*}{ Heavy Metals } & S1 & S2 & S3 & \multicolumn{2}{c}{ Limit Values $\left(\mathbf{m g ~ k g}^{-\mathbf{1}} \mathbf{D W}\right)$} \\
& & $\mathbf{~ m g ~ k g}^{-\mathbf{1}} \mathbf{D W}$ & & EU Organic Agriculture & [41] & [30] & [29] \\
\hline $\mathrm{Cr}$ & $11.34 \pm 0.08$ & $11.63 \pm 0.05$ & $19.42 \pm 0.29$ & 70 & 100 & 100 & 60 \\
$\mathrm{Co}$ & $0.53 \pm 0.06$ & $0.45 \pm 0.09$ & $2.18 \pm 0.01$ & - & - & - & - \\
$\mathrm{Cu}$ & $3.49 \pm 0.01$ & $4.32 \pm 0.68$ & $5.9 \pm 0.55$ & 70 & 100 & 200 & 300 \\
$\mathrm{Ni}$ & $1.05 \pm 0.01$ & $1.89 \pm 0.06$ & $2.78 \pm 0.05$ & 25 & 50 & 50 & 40 \\
$\mathrm{Zn}$ & $0.95 \pm 0.03$ & $1.12 \pm 0.08$ & $1.43 \pm 0.06$ & 200 & 300 & 400 & 600 \\
\hline
\end{tabular}


Table 2. Pearson's correlation matrix of heavy metal concentrations in the compost samples.

\begin{tabular}{llllll}
\hline & \multicolumn{1}{c}{ Cr } & \multicolumn{1}{c}{ Co } & \multicolumn{1}{c}{ Ni } & Cu & Zn \\
\hline $\mathrm{Cr}$ & 1 & & & & \\
$\mathrm{Co}$ & $0.989^{* *}$ & 1 & & & \\
$\mathrm{Ni}$ & $0.886^{* *}$ & $0.850^{* *}$ & 1 & & \\
$\mathrm{Cu}$ & $0.800^{*}$ & $0.707^{*}$ & $0.793^{*}$ & 1 & \\
$\mathrm{Zn}$ & $0.846^{* *}$ & $0.862^{* *}$ & $0.914^{* *}$ & 0.526 & 1 \\
\hline \multicolumn{7}{c}{$p<0.05^{* *} p<0.01}$.
\end{tabular}

Results showed that the concentrations of $\mathrm{Ca}$ in the obtained compost decreased in the following order: S3 > S2 > S1 $(1163.46 \pm 0.32,998.61 \pm 0.36$, and $736.08 \pm 0.62 \mathrm{mg} / \mathrm{kg} \mathrm{DW})$. The highest $\mathrm{Mg}$ concentration was observed in compost obtained from S3 $(493.41 \pm 0.3 \mathrm{mg} / \mathrm{kg} \mathrm{DW})$, followed by compost from S2 $(356.03 \pm 0.58 \mathrm{mg} / \mathrm{kg} \mathrm{DW})$ and by compost from S1 $(328.19 \pm 0.11 \mathrm{mg} / \mathrm{kg} \mathrm{DW})$. $\mathrm{Na}$ concentrations in the obtained compost decrease in the following order: S2 > S3 > S1 (511.4 \pm 0.35 , $415.4 \pm 0.33$, and $364.48 \pm 0.29 \mathrm{mg} / \mathrm{kg}$ DW).

Mesophilic bacteria grow in the mesophilic and thermophilic stages, when intense degradation of organic matter occurs. During the composing process the microbial communities are constantly changing [42]. According to [43] an increase of microorganism number represents more extensive and rapid biodegradation during composting, while decreasing of microorganism number at the end of the process means that the compost is mature and stable. For the first sample the higher number of microorganisms is registered in week two for mesophilic aerobic bacteria (MAB), followed by yeasts and molds (YM) and lactic bacteria (LB). From Figure $6 a$ it can be observed that the number of MAB is increasing in the first two weeks of composting and then decreased, the number of LB fluctuates during the composting process, while the number of yeasts and molds is decreasing. The number of coliform bacteria (CB) is decreasing during the composting process. The same tendency of the microorganism number and type was observed during the composting of the other two samples (Figure $6 \mathrm{~b}, \mathrm{c}$ ). On the second week of the composting process, the MAB counts for samples were $3.64 \times 10^{7} \mathrm{CFU} / \mathrm{g}(\mathrm{S} 3), 8.28 \times 10^{7} \mathrm{CFU} / \mathrm{g}(\mathrm{S} 2)$, and $1.08 \times 10^{8} \mathrm{CFU} / \mathrm{g}(\mathrm{S} 1)$, respectively. The number of $\mathrm{MAB}$ decreased in the five weeks to $5.96 \times 10^{7} \mathrm{CFU} / \mathrm{g}$ for S1, $6.39 \times 10^{7} \mathrm{CFU} / \mathrm{g}$ for S2, and increased for S3 $\left(5.00 \times 10^{7} \mathrm{CFU} / \mathrm{g}\right)$ and then followed a downward trend until the end of composting. This tendency of increasing and decreasing of MAB number during the composting process was also observed by [42]. In [44] the authors counted in the first 10 days of composting 1.7-2.84 $\times 10^{9} \mathrm{CFU} / \mathrm{g} \mathrm{MAB}$, having a larger number of aerobic bacteria than us. The authors of [44] also observed a decrease in the MAB number to $10^{7} \mathrm{CFU} / \mathrm{g}$ in the seventh week, until $10^{6}-10^{5} \mathrm{CFU} / \mathrm{g}$ in the maturation phase. The same tendency was also observed in our case. The highest decrease in the number can be seen in the case of $\mathrm{CB}$. The results show that the $\mathrm{CB}$ reduction obtained was from $4.77 \times 10^{6} \mathrm{CFU} / \mathrm{g}$ to $2.20 \times 10^{1} \mathrm{CFU} / \mathrm{g}$ (S1), from $6.48 \times 10^{6} \mathrm{CFU} / \mathrm{g}$ to $1.10 \times 10^{1} \mathrm{CFU} / \mathrm{g}$ (S2), and from $4.32 \times 10^{6} \mathrm{CFU} / \mathrm{g}$ to $4.00 \times 10^{1} \mathrm{CFU} /(\mathrm{S} 3$ ). The microorganism counts were transformed to log values (Figure 6). 


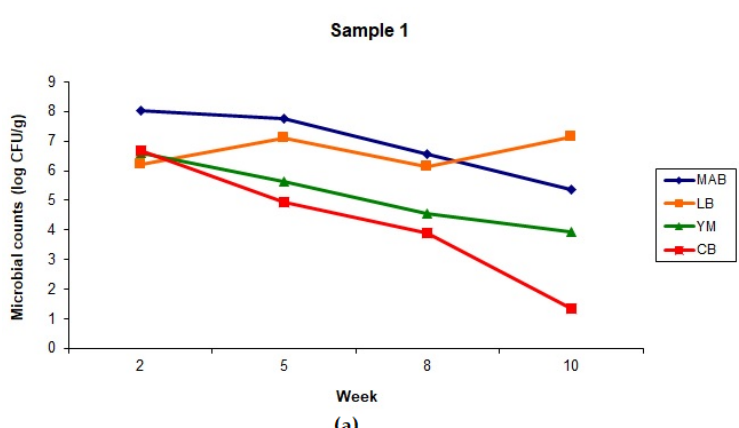

(a)

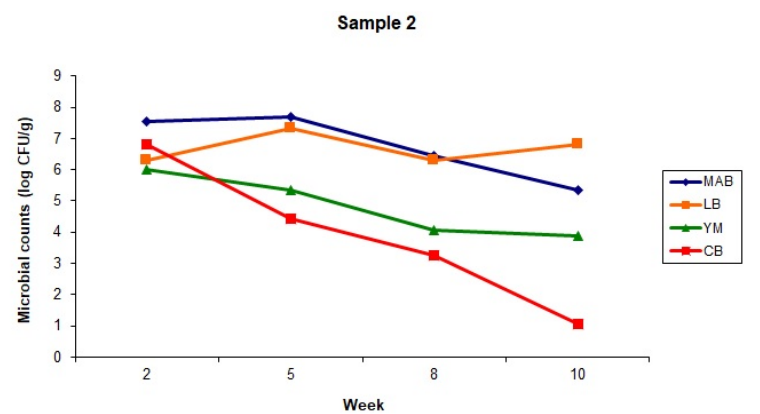

(b)

Sample 3

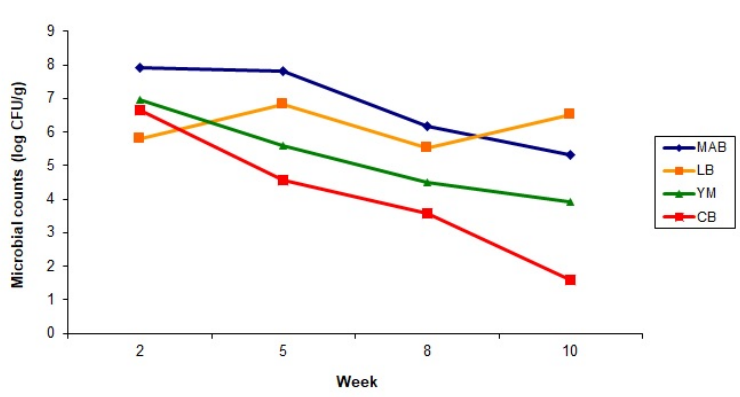

(c)

Figure 6. Evolution of the microorganism number during the experiment: (a) S1, (b) S2, (c) S3 (MAB-mesophilic aerobic bacteria, LB-lactic bacteria, YM-yeasts and molds, CB-coliform bacteria).

From Table 3, it can be observed that the Pearson correlation between $\mathrm{pH}$ and EC is 0.543 which indicates that is a moderate positive relationship between these two variables and a strongly negative relationship between $\mathrm{pH}$ and LB $(-0.702)$ ( $p$-value $<0.05)$. A strongly positive relationship can be observed between EC and CB (0.846) and YM (0.770) ( $p$-value < 0.05), so it is considered that all variables increase when one of these three variables is increasing. It was observed that strongly positive relationships are between $\mathrm{M}$ and MAB (0.963), $\mathrm{M}$ and CB (0.944), and $\mathrm{M}$ and $\mathrm{YM}(0.852)(p$-value $=0.000)$ (Table 3). Moderate negative relationships are between $\mathrm{N}$ and $\mathrm{MAB}, \mathrm{N}$ and $\mathrm{YM}$, and $\mathrm{N}$ and $\mathrm{CB}$.

Table 3. Correlation matrix (Pearson correlation).

\begin{tabular}{llllllllll}
\hline & $\mathbf{p H}$ & $\mathbf{E C}$ & $\mathbf{M}$ & $\mathbf{N}$ & $\mathbf{C}$ & $\mathbf{C} / \mathbf{N}$ & $\mathbf{M A B}$ & $\mathbf{L B}$ & $\mathbf{Y M}$ \\
\hline EC & 0.543 & & & & & & & & \\
M & 0.310 & 0.661 & & & & & & & \\
N & 0.259 & -0.233 & -0.505 & & & & & & \\
C & 0.395 & 0.679 & 0.808 & -0.647 & & & & & \\
C/N & 0.094 & 0.460 & 0.766 & -0.848 & 0.916 & & & & \\
MAB & 0.170 & 0.601 & 0.963 & -0.572 & 0.766 & 0.771 & & & \\
LB & -0.702 & -0.593 & -0.193 & -0.469 & -0.032 & 0.245 & -0.037 & & \\
YM & 0.224 & 0.770 & 0.852 & -0.491 & 0.720 & 0.678 & 0.913 & -0.204 & \\
CB & 0.359 & 0.846 & 0.944 & -0.470 & 0.821 & 0.727 & 0.919 & -0.331 & 0.939 \\
\hline
\end{tabular}

The principal component analysis was performed, and it was observed that the first two components have eigenvalues greater than 1 (Table 4). The first component has a proportion of 0.626 , which means that it explains $62.6 \%$ of the variability in the data and the second component has $23.7 \%$ and can both be included in the evaluation, while the other components have lower proportions and may not be important enough to be included into the evaluation. The first component has a positive association with CB (0.389), M (0.377), and MAB (0.371), while the second component has a large negative association with $\mathrm{pH}(-0.497)$ and $\mathrm{N}(-0.444)$. 
Table 4. Principal component analysis: $\mathrm{pH} ; \mathrm{EC} ; \mathrm{M} ; \mathrm{N} ; \mathrm{C} ; \mathrm{C} / \mathrm{N} ; \mathrm{MAB} ; \mathrm{LB} ; \mathrm{YM} ; \mathrm{CB}$.

\begin{tabular}{ccccccccccc}
\hline Eigenvalue & 62.611 & 23.681 & 0.6583 & 0.3710 & 0.1617 & 0.1132 & 0.0496 & 0.0129 & 0.0025 & 0.0017 \\
Proportion & 0.626 & 0.237 & 0.066 & 0.037 & 0.016 & 0.011 & 0.005 & 0.001 & 0.000 & 0.000 \\
Cumulative & 0.626 & 0.863 & 0.929 & 0.966 & 0.982 & 0.993 & 0.998 & 1.000 & 1.000 & 1.000 \\
& & & \multicolumn{7}{c}{ Eigenvectors } \\
Variable & PC1 & PC2 & PC3 & PC4 & PC5 & PC6 & PC7 & PC8 & PC9 & PC10 \\
\hline pH & 0.140 & -0.497 & -0.586 & -0.314 & -0.107 & -0.474 & 0.146 & 0.119 & 0.129 & 0.046 \\
EC & 0.317 & -0.299 & 0.044 & 0.597 & -0.286 & 0.170 & 0.455 & 0.291 & -0.198 & -0.105 \\
M & 0.377 & -0.007 & 0.157 & -0.408 & 0.364 & 0.233 & 0.273 & 0.126 & 0.217 & -0.585 \\
N & -0.246 & -0.444 & 0.202 & -0.419 & -0.459 & 0.476 & -0.214 & 0.179 & -0.100 & -0.001 \\
C & 0.364 & 0.063 & -0.439 & 0.004 & -0.222 & 0.413 & -0.093 & -0.657 & -0.067 & -0.071 \\
C/N & 0.340 & 0.275 & -0.340 & -0.001 & 0.082 & 0.157 & -0.499 & 0.600 & -0.224 & 0.052 \\
MAB & 0.371 & 0.083 & 0.293 & -0.387 & 0.009 & -0.169 & 0.236 & -0.106 & -0.612 & 0.386 \\
LB & -0.074 & 0.609 & -0.104 & -0.216 & -0.584 & -0.036 & 0.369 & 0.186 & 0.228 & -0.012 \\
YM & 0.367 & -0.024 & 0.377 & 0.072 & -0.407 & -0.459 & -0.448 & -0.112 & 0.105 & -0.343 \\
CB & 0.389 & -0.092 & 0.205 & 0.016 & 0.029 & 0.172 & -0.032 & 0.044 & 0.629 & 0.608 \\
\hline
\end{tabular}

Food waste composition directly influences the activity of microorganisms. Poisson regression analysis was applied in order to find the relation between microorganisms and physico-chemical indicators. After examination of goodness-of-fit results it was observed that is no statistically significant evidence of lack-of-fit $(p>0.9)$. The obtained Akaike information criterion (AIC) values were 59.35, 58.86, 56.04, and 51.97. The model fits the data better if the AIC has smaller values. The variance inflation factor (VIF) is between 1 and 5 for $\mathrm{pH}, \mathrm{EC}$, and $\mathrm{M}$, which means that these indicators are moderately correlated, while for $\mathrm{N}, \mathrm{C}$, and $\mathrm{C} / \mathrm{N}$ exceeds a value of 5 which means they are highly correlated. The deviance $\left(\mathrm{R}^{2}\right)$ is $95.78 \%$ for $\mathrm{MAB}, 85.03 \%$ for $\mathrm{LB}, 87.15 \%$ for $\mathrm{YM}$, and $97.78 \%$ for $\mathrm{CB}$. The following regression equations were obtained: when $\mathrm{MAB}=\exp \left(\mathrm{Y}^{\prime}\right)$

$$
-\mathrm{Y}^{\prime}=1.45-0.014 \mathrm{pH}-0.00001 \mathrm{EC}+0.0117 \mathrm{M}-0.07 \mathrm{~N}+0.0003 \mathrm{C}-0.0025 \mathrm{C} / \mathrm{N},
$$

when $\mathrm{LB}=\exp \left(\mathrm{Y}^{\prime}\right)$

$$
-\mathrm{Y}^{\prime}=2.13-0.053 \mathrm{pH}-0.0003 \mathrm{EC}-0.0015 \mathrm{M}-0.032 \mathrm{~N}+0.012 \mathrm{C}-0.0004 \mathrm{C} / \mathrm{N},
$$

when $\mathrm{YM}=\exp \left(\mathrm{Y}^{\prime}\right)$

$$
-\mathrm{Y}^{\prime}=1.47-0.033 \mathrm{pH}+0.0006 \mathrm{EC}+0.0095 \mathrm{M}+0.00 \mathrm{~N}-0.017 \mathrm{C}+0.0074 \mathrm{C} / \mathrm{N},
$$

when $\mathrm{CB}=\exp \left(\mathrm{Y}^{\prime}\right)$

$$
-\mathrm{Y}^{\prime}=-1.36+0.008 \mathrm{pH}+0.0005 \mathrm{EC}+0.0404 \mathrm{M}-0.16 \mathrm{~N}+0.009 \mathrm{C}-0.0149 \mathrm{C} / \mathrm{N} \text {, }
$$

Deviance residual plots for $\mathrm{CB}$ are illustrated in Figure 7. It can be observed that one point is away from the line, but after the Grubbs' test it was concluded that this point is furthest from the rest, but not a significant outlier $(p>0.05)$. 


\section{Deviance Residual Plots for CB}
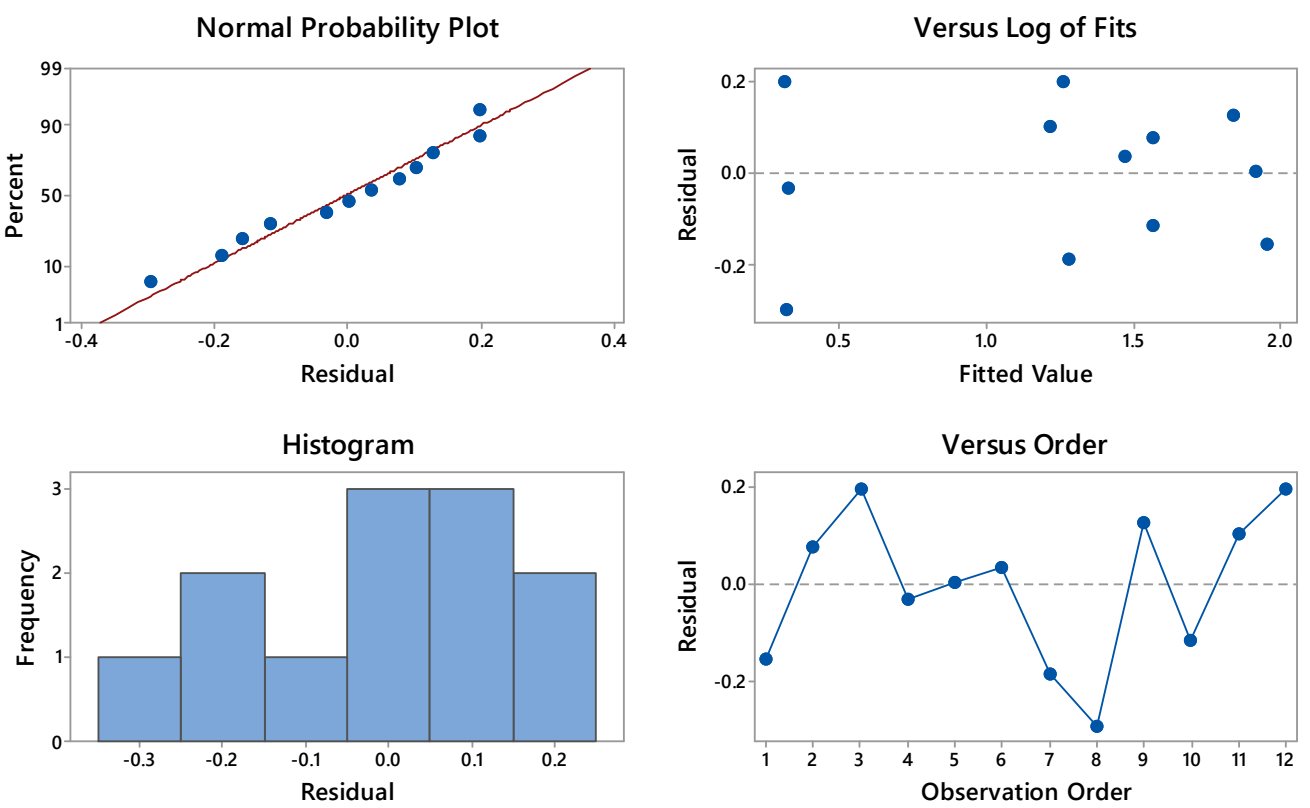

Figure 7. Deviance residual plots for CB.

\section{Conclusions}

In this study, the possibility of obtaining quality compost from fruit and vegetable waste at laboratory level was investigated in order to establish the relationship between microorganisms and physico-chemical parameters. In conclusion, the determination of sample compositions based on the mathematical calculations used to obtain the three desired C/N ratios (31.42 (S3), 44.9 (S2), and 49.61 (S1)) proved to be effective since after the practical analyses the following $\mathrm{C} / \mathrm{N}$ ratios were determined: 30.62 (S3), 45.20 (S2), and 50.22 (S1). The compost was successfully obtained, and its quality was not compromised by the high moisture content $(74 \%-81 \%)$, also, the compost samples meet the requirement standards for agricultural use having a low content of heavy metals. We observed that strongly positive relationships are between moisture and carbon contents, moisture and coliform bacteria, moisture and $\mathrm{C} / \mathrm{N}$ ratio, while electrical conductivity has a large negative association with mesophilic aerobic bacteria, followed by yeasts and molds and lactic bacteria (when the electrical conductivity values increase the number of these microorganisms is decreasing). Based on the results obtained by applying statistical analysis it can be concluded that there is a statistically significant association between the microorganisms and physico-chemical indicators.

This study is useful since the obtained results showed that it is necessary, before the beginning of any composting process, to establish the working conditions and to use mathematical relationships (as well as software like Minitab) to determine and obtain the values, for example of $\mathrm{C} / \mathrm{N}$ ratios, desired in practice. Our results highlight the relationships between physico-chemical properties and microorganism development during the composting process. These relationships can be used further to improve the composting process. This study has some limitations, such as lack of replicate evidence, the amount of waste used, and the fact that the study was conducted only at laboratory level, but in the future research we will take into consideration these aspects and we will also establish other conditions for obtaining compost.

Author Contributions: C.G., A.L. conceived and designed the experiments, C.G., A.L. performed the experiments, C.G., A.L. analyzed the data, C.G. wrote the paper. All authors have read and agree to the published version of the manuscript.

Funding: This research was funded by Stefan cel Mare University of Suceava, Romania.

Conflicts of Interest: The authors declare no conflict of interest. 


\section{References}

1. Eurostat. Municipal Waste by Waste Management Operations. Available online: http://appsso.eurostat.ec. europa.eu/nui/submitViewTableAction.do (accessed on 20 January 2020).

2. NWMP. National Waste Management Plan. Available online: http://www.mmediu.ro/app/webroot/uploads/ files/PNGD_vers5.pdf (accessed on 26 November 2018).

3. Cerda, A.; Artola, A.; Font, X.; Barrena, R.; Gea, T.; Sánchez, A. Composting of food wastes: Status and challenges. Bioresour. Technol. 2018, 248, 57-67. [CrossRef]

4. Inglezakis, V.; Dvorsak, S.; Varga, J.; Venetis, C.; Zorpas, A.; Elaiopoulos, K.; Ardeleanu, N.; Ilieva, L.; Moustakas, K.; Loizidou, M.; et al. Municipal solid waste experimental studies in Romania and Bulgaria. Int. J. Chem. Environ. Eng. Syst. 2012, 3, 64-73.

5. Ghinea, C.; Petraru, M.; Bressers, H.T.A.; Gavrilescu, M. Environmental evaluation of waste management scenarios - significance of the boundaries. J. Environ. Eng. Landsc. 2012, 20, 76-85. [CrossRef]

6. EC. Directive (EU) 2018/851 of the European Parliament and of the Council of 30 May 2018 amending Directive 2008/98/EC on waste. Off. J. Eur. Union 2018, L 150, 109-140.

7. Bhatia, A.; Madan, S.; Sahoo, J.; Ali, M.; Pathania, R.; Kazmi, A.A. Diversity of bacterial isolates during full scale rotary drum composting. Waste Manag. 2013, 33, 1595-1601. [CrossRef]

8. Onwosi, C.O.; Igbokwe, V.C.; Odimba, J.N.; Eke, I.E.; Nwankwoala, M.O.; Iroh, I.N.; Ezeogu, L.I. Composting technology in waste stabilization: On the methods, challenges and future prospects. J. Environ. Manag. 2017, 190, 140-157. [CrossRef]

9. Ghinea, C.; Gavrilescu, M. Costs analysis of municipal solid waste management scenarios: Iasi-Romania case study. J. Environ. Eng. Landsc. 2016, 24, 185-199. [CrossRef]

10. Ghinea, C.; Gavrilescu, M. Solid Waste Management for Circular Economy: Challenges and Opportunities in Romania-The Case Study of Iasi County. In Towards Zero Waste. Greening of Industry Networks Studies; Franco-García, M.L., Carpio-Aguilar, J., Bressers, H., Eds.; Springer: Cham, Germany, 2019; Volume 6, pp. 25-60.

11. De Laurentiis, V.; Corrado, S.; Sala, S. Quantifying household waste of fresh fruit and vegetables in the EU. Waste Manag. 2018, 77, 238-251. [CrossRef]

12. Ghinea, C.; Ghiuta, O.A. Household food waste generation: Young consumers behaviour, habits and attitudes. Int. J. Environ. Sci. Technol. 2019, 16, 2185-2200. [CrossRef]

13. Dumitrescu, L.; Manciulea, I.; Sauciuc, A.; Zaha, C. Obtaining fertilizer compost by composting vegetable waste, sewage sludge and sawdust. Bull. Transilv. Univ. Brasov Ser. I 2009, 2, 117-122.

14. Kulcu, R. Composting of greenhouse tomato plant residues, wheat straw, and separated dairy manure, and the effect of free air space on the process. Pol.J. Environ. Stud. 2014, 23, 1341-1346.

15. Nakasaki, K.; Mimoto, H.; Tran, Q.N.M.; Oinuma, A. Composting of food waste subjected to hydrothermal pretreatment and inoculated with Paecilomyces sp. FA13. Bioresour. Technol. 2015, 180, 40-46. [CrossRef]

16. Manu, M.K.; Kumar, R.; Garg, A. Drum Composting of Food Waste: A Kinetic Study. Proced. Environ. Sci. 2016, 35, 456-463. [CrossRef]

17. Manu, M.K.; Kumar, R.; Garg, A. Performance assessment of improved composting system for food waste with varying aeration and use of microbial inoculum. Bioresour. Technol. 2017, 234, 167-177. [CrossRef]

18. Ghinea, C.; Apostol, L.C.; Prisacaru, A.E.; Leahu, A. Development of a model for food waste composting. Environ. Sci. Pollut. Res. 2019, 26, 4056-4069. [CrossRef]

19. Jurado, M.; López, M.J.; Suárez-Estrella, F.; Vargas-García, M.C.; López-González, J.A.; Moreno, J. Exploiting composting biodiversity: Study of the persistent and biotechnologically relevant microorganisms from lignocellulose-based composting. Bioresour. Technol. 2014, 162, 283-293. [CrossRef]

20. López-González, J.A.; López, M.J.; Vargas-García, M.C.; Suárez-Estrella, F.; Jurado, M.; Moreno, J. Tracking organic matter and microbiota dynamics during the stages of lignocellulosic waste composting. Bioresour. Technol. 2013, 146, 574-584. [CrossRef]

21. Nasreen, Z.; Qazi, J.I. Lab Scale Composting of Fruits and Vegetable Waste at Elevated Temperature and Forced Aeration. Pak. J. Zool. 2012, 44, 1285-1290.

22. Hefnawy, M.; Gharieb, M.; Nagdi, O.M. Microbial diversity during composting cycles of rice straw. Int. J. Adv. Biol. Biomed. Res. 2013, 1, 232-245. 
23. Bohacz, J. Microbial strategies and biochemical activity during lignocellulosic waste composting in relation to the occurring biothermal phases. J. Environ. Manag. 2018, 206, 1052-1062. [CrossRef]

24. Ryckeboer, J.; Mergaert, J.; Coosemans, J.; Deprins, K.; Swings, J. Microbiological aspects of biowaste during composting in a monitored compost bin. J. Appl. Microbiol. 2003, 94, 127-137. [CrossRef]

25. Sundberg, C.; Yu, D.; Franke-Whittle, I.; Kauppi, S.; Smårs, S.; Insam, H.; Romantschuk, M.; Jönsson, H. Effects of $\mathrm{pH}$ and microbial composition on odour in food waste composting. Waste Manag. 2013, 33, $204-211$. [CrossRef]

26. Chan, M.; Selvam, A.; Wong, J.W.C. Reducing nitrogen loss and salinity during 'struvite' food waste composting by zeolite amendment. Bioresour. Technol. 2016, 200, 838-844. [CrossRef]

27. Li, Z.; Lu, H.; Ren, L.; He, L. Experimental and modeling approaches for food waste composting: A review. Chemosphere 2013, 93, 1247-1257. [CrossRef]

28. Vázquez, M.A.; Sen, R.; Soto, M. Physico-chemical and biological characteristics of compost from decentralised composting programmes. Bioresour. Technol. 2015, 198, 520-532. [CrossRef]

29. European Compost Network. Guidelines Specification for the Use of Quality Compost in Growing Media, Part D of the ECN QAS Quality Manual. Available online: https://www.compostnetwork.info/ecn-guidelinesfor-use-of-quality-compost/ (accessed on 25 February 2019).

30. WRAP. Guidelines for the Specification of Quality Compost for Use in Growing Media. Available online: http://www.wrap.org.uk/sites/files/wrap/Growing_Media_Specification.pdf (accessed on 26 November 2018).

31. Barrena, R.; Font, X.; Gabarrell, X.; Sánchez, A. Home composting versus industrial composting: Influence of composting system on compost quality with focus on compost stability. Waste Manag. 2014, 34, 1109-1116. [CrossRef]

32. Yu, H.; Xie, B.; Khan, R.; Shen, G. The changes in carbon, nitrogen components and humic substances during organic-inorganic aerobic co-composting. Bioresour. Technol. 2019, 271, 228-235. [CrossRef]

33. Zhang, L.; Sun, X. Changes in physical, chemical and microbiological properties during the two-stage co-composting of green waste with spent mushroom compost and biochar. Bioresour. Technol. 2014, 171, 274-284. [CrossRef]

34. Cáceres, R.; Coromina, N.; Malinska, K.; Martínez-Farré, F.X.; López, M.; Soliva, M.; Marfà, O. Nitrification during extended co-composting of extreme mixtures of Green waste and solid fraction of cattle slurry to obtain growing media. Waste Manag. 2016, 58, 118-125. [CrossRef]

35. Brito, L.M.; Mourao, I.; Coutinho, J.; Smith, S.R. Simple technologies for on-farm composting of cattle slurry solid fraction. Waste Manag. 2012, 32, 1332-1340. [CrossRef]

36. Petric, I.; Avdihodzic, E.; Ibric, N. Numerical simulation of composting process for mixture of organic fraction of municipal solid waste and poultry manure. Ecol. Eng. 2015, 75, 242-249. [CrossRef]

37. Yang, F.; Li, G.; Shi, H.; Wang, Y. Effects of phosphogypsum and superphos-phate on compost maturity and gaseous emissions during kitchen waste composting. Waste Manag. 2015, 36, 70-76. [CrossRef] [PubMed]

38. Kim, J.D.; Park, J.S.; In, B.H.; Kim, D.; Namkoong, W. Evaluation of pilot-scale in-vessel composting for food waste treatment. J. Hazard. Mater. 2008, 154, 272-277. [CrossRef] [PubMed]

39. Lin, C. A negative-pressure aeration system for composting food wastes. Bioresour. Technol. 2008, 99, 7651-7656. [CrossRef] [PubMed]

40. Yang, X.; Li, Q.; Tang, Z.; Zhang, W.; Yu, G.; Shen, Q.; Zhao, F.J. Heavy metal concentrations and arsenic speciation in animal manure composts in China. Waste Manag. 2017, 64, 333-339. [CrossRef] [PubMed]

41. EC. EU ECO Label, 64/2007 Eco-Label to Growing Media and 799/2006 Eco-Label to Soil Improvers; EU Regulation on Organic Agriculture, 889/2008, Compliance with Limits Required for Compost from Source Separated Bio-Waste Only; European Commission: Brussel, Belgium, 2016.

42. Vishan, I.; Kanekar, H.; Kalamdhad, A. Microbial population, stability and maturity analysis of rotary drum composting of water hyacinth. Biologia 2014, 69, 1303-1313. [CrossRef] 
43. Zhang, L.; Sun, X. Influence of bulking agents on physical, chemical, and microbiological properties during the two-stage composting of green waste. Waste Manag. 2016, 48, 115-126. [CrossRef]

44. Chandna, P.; Nain, L.; Singh, S.; Kuhad, R.C. Assessment of bacterial diversity during composting of agricultural byproducts. BMC Microbiol. 2013, 13, 99. [CrossRef] 